\title{
PENDIDIKAN SEBAGAI PROSES TRANSMISI SOSIAL BUDAYA
}

\author{
Wahyudi Buska \\ Yogia Prihartini \\ Universitas Islam Negeri Sulthan Thaha Saifuddin Jambi \\ wahyudi@uinjambi.ac.id
}

\begin{abstract}
Abstrak
Pelaksanaan pendidikan merupakan warisan kebudayaan dari generasi kegenerasi agar identitasa masyarakat lebih terpelihara, Pendidikan dapat memebentuk seseorang lebih baik sebelum ia didik.Melalui pendidikanlah bagaimana dijarkan nilai-nilai kebaikan kepada seseorang, sehingga ia mengetahui mana yang baik, dan mana yang buruk. Di antara solusi yang yang perlu diperhitungkan adalah bagaimana upaya dalam membentuk kepribadian dan perubahan tingkah laku individu atau masyarakat. Pendidikan bernuansa budaya merupakan salah satu solusi dalam mengatasi permasalahan yang terjadi dalam dunia pendidikan, khususnya masalah maraknya tawuran dan kerusuhan dan demonstrasi yang terjadi akhir-akhir ini. Pendidikan yang terdiri dari pendidikan formal dan pendidikan non formal merupakan elemen penting dalam menciptakan pendidikan bernuansa budaya tersebut. Dengan demikian pendidikan bernuansa budaya diharapkan dapat menghasilkan produk pendidikan yang menjunjung nilai-nilai budaya dan nilai-nilai kepribadian.
\end{abstract}

Keyword: pendidikan, transmisi, social, budaya

\section{PENDAHULUAN}

Segala aktivitas dalam dunia pendidikan selalu berkenaan dengan upaya pembinaan manusia, maka keberhasilan pendidikan sangat bergantung kepada unsur manusianya, karena manusia paling menentukan berhasil atau tidaknya suatu pendidikan. Sarana adalah pihak kedua yang terkait dalam unsur pendidikan, dan tidak kalah penting dari rumah dan masyarakat,bahkan dengan perbedaan waktu,tempat serta faktor-faktor yang lain, peranan sekolah dapat melampawi peranan rumah dan masyarakat.Sekolah melaksanakan tugas pendidikan, yakni merealisasikan tujuan yang ingin dicapai serta berperan memikul tanggung jawab umum dan mempersiapkan anak untuk membangun generasi yang lebih maju.

$$
\text { يرفع الله الذين امنو امنكم وللذ ين اوتو ا العلم درجا ت }
$$

\section{Allah akan meninggikan orang-orang yang beriman di antar kamu} dan orang-orang yang berilmu pengetahuan beberapa derajat ( AlMujadalah :11)

Allah SWT akan mengasihi dan menyayangi bagi hamba-Nya yang beriman dan berilmu,begitu besar perhatian Allah bagi hambanya yang senantiasa 
taat melaksanakan segala perintahnya dan menjauhi segala larangan-Nya, bukan hanya sekedar itu saja tapi Allah akan memberikan balasan berupa sorga yang mengalir air sungai dibawahnya di samping itu juga Allah SWT selalu memberikan rahmat serta perlindungan yang senantiasa taat kepada--Nya.

Menurut Talcott Parsons adalah figur sentral dalam teori sosiologi abad ke20. Parsons secara sistematis berupaya membuat teori yang menjelaskan hubungan antara kebudayaan, kepribadian, dan struktur sosial dengan secara mengembangkan model yang abstrak namun bisa diterapkan secara universal.Ia juga termasuk pemikir awal yang berjasa menyebarluaskan benih-benih pemikiran sosialogi kulturalnya Durkheim dan Weber.Parsons menjadi figur pokok yang memperkenalkan fungsionalisme sebagai paradigma intelektual. Tanggapan kritis terhadap karya-karyanya menjadi landasan bagi sejumlah karya dan penemuan baru menyangkut tema kebudayaan. Memahami karya Persons akan membantu kita dalam memahami teori-teori kebudayaan kontemporer. (Nur Uhbiyati, 1998: 91-92)

Apa yang telah dijelaskan oleh Parsons tentang kebudayaan serta struktur sosial, merupaka suatu pemikiran yang membahas tentang prilaku masyarakat, hidup dan berkembang serta berprilaku antara satu individu dengan individu lainnya, ini perlu diketahui agar kehidupan kita dimasyarakat dapat berjalan dengan sesungguhnya.

Parsons adalah figur terkemuka dalam ranah sosiologi Amerika. Dalam bukunya ia menyerang model subjek pelaku tindakan yang rasional. Model subjek ppelaku yang rasional adalah"musuh besar" dari hampir semua pendekatan kebudayaan. Model ini cenderung berganti jubah sepanjang wakinner dan Ivan Pavlop yang memberikan tekanan pada rangsangan (stimulus) dan ganjaran (rewoard).

Kalau kita lihat apa yang dilakukan oleh B.F. Skinner dan Pavlov ini kita hidup bermasyarakat, serta berprilaku sosial adanya suatu keinginan dari hati sanubari dikernakan adanya rasa ingin bertegur sapa dan ingin bergaul adanya kepedulian terhadap orang lain, ada rasa saling menyanyangi dan menghargai antara satu dengan yang lain serta saling membuthkan.Teori ini masih berkaitan degnan teori Homans dan Blau,bahwa orang cenderung memaksimalkan sejumlah hal tertentu berinteraksi sosial bilamana ada keuntungan untuk melakukannya.Di jantung The Structure of Sucial Action terletak model unit tindakan (the unit act),yaitu sebuah model adeal tindakan manusia yang harus mempunyai nilia unsur tindakan:1.Tujuan (ends) tujuan tindakan, 2.Sarana (meands) hal-hal yang mempunyai si pelaku bertindak, 3.Syarat (conditions) stuasi kondisi dan batasanbatasan yang melingkupi tindakan, 4.Norma(Noems) pemahaman atas tujuan dan sarana mana yang sesuai dan bisa diterima, 5.Upaya(effort) upaya yang dikerahkan pelaku untuk menyelesaikan tindakan.

Dengan mengemukan teori ini tentu kita mengetahui bahwa manusia itu memiliki segala kemampuan untuk melakukan suatu tindakan atau rangsangan yang dapat merangkai suatu keinginan yang bisa dipahami kompleks dan seimbang. Peran struktur sosial dalam hubungan dengan tindak sosial,interaksi sosial, dan perilaku peran. Jalan mengenai struktur sosial memusatkan sosial sebagai pengawanjantahan struktur tersebut.Secara keseluruhan, inilah yang 
menyebabkan munculnya analisis"mikroskopis" yang ditunjuk oleh nibet.Pada tataran deskripsi,pendekatan ini sangat masuk akal karena bagaimanapun juga kita amati dalam penelitian lapangan adalah tindak serta interaksi individu (David Kaplan, 2012: 149).

Dalam kehidupan kemasyarakatan perlu adanya interaksi serta tindakan memikirkannya serta mengamtinya secara lebih mendalam tentang kehidupan bermasyarakat yang dilakukan oleh individu.

Interaksi pendidikan, kalau kita berasumsi bahwa pendidikan merupakan suatu cara terbaik tentu mengubah mutu SDM, masyarakat umum sudah mengetahui bahwa yang disebut lembaga pendidikan itu identik dengan sekolah. Konsep ini tidak seluruhnya benar karena UU Nomor 2 Tahun 1992 mengaakui lembaga (institusi) pendidikan yang berlangsung di luar sekolah yang dahulu disebut pendidikan formal. Namun ada baiknya kita mengetahui dahulu konsep yang paling tua dipakai manusia yakni menyamakan lembaga pendidikan dengan sekolah.

Menurut Wabster (1991:45), sekolah merupakan tempat atau instansi/lembaga yang secara khusus didirikan untuk menyelenggarakan proses belajar mengajar atau pendidikan. Sebagai istitusi sekolah merupakan tempat untuk mengajar murid-murid, tempat untuk melatih dan memberi instruksiinstruksi tentang suatu lapangankeilmuan dan keterampilan tertentu kepada para siswa.Tempat yang dinamaka sekolah itu merupakan satu kompleks bangunan,laboratorium,fasilitas fisik yang disediakan sebagai pusat kegiatan belajar dan mengajar.

Berdasarkan pendapat itu maka sekolah mengandung dua makna, secara fisik sekolah terdiri dari bangunan-bangunan, gedung dan laboratorium, jadi sekolah dalam artian material. Sedangkan yang non-fisik terdiri dari sistem hubungan antara mereka yang ditugaskan untuk mengajar (guru), pelatih dan lainlain),dengan yang diajar (murid,siswa), jadi sekolah dalam lain-lain.) dengan yang diajar (murid,siswa), jadi sekolah dalam artian spiritual.

Kedua artian tersebut di atas saling mendukung,misalnya guru tidak bisa mengajar, mensosialisasikan nilai-nilai (artian spiritual) dengan sempurna apabila tidak didukung oleh fasilitas (artian matrial) belajar mengajar yang memadai. Baik artian material maupun spiritual, sekolah tetap sekolah, dia merupakan suatu "area" khusus dalam strata sosial dan budaya masyarakat sehingga eksistensi sekolah yang mendidik manusia tidak dapat dipisahkan dengan konteks masyarakat.

Kedudukan manusia dalam lingkungan sosial dan budaya masyarakat:Masyarakat,komunitas, organisasi keluarga, individu.Sekolah merupakan tempat lembaga (institusi) pendidikan menyelenggarakan seluruh kegiatannya baik praktis maupun substantif. Dalam rangka sosialisasi nilai, maka masyarakat kita menghadapi dua masalah aktual :1), Keadaan sosial budaya masyarakat turut mempengaruhi penyelenggaraan pendidikan.2).Keadaan dibidang pendidikan khususnya tingkat partisipasi masyarakat dan anak didik yang memelihara konsep pendidikan berkelanjutan.

Berdasarkan kondisi sosial budaya masyarakat ditentukan oleh faktor sosial dan budaya yang membentuknya. Hal ini berkaitan erat dengan ketidak- 
terpisahan antara masyarakat dengan kebudayaan dalam semacam aksioma :tidak ada masyarakat tanpa kebudayaan dan tidak kebudayaan tanpa masyarakat. Menengok kembali keadaan masyarakat Indonesia, harus diakui masyarakat Indonesia merupakan masyarakat majmuk. Kemajmukan itu terlihat dalam keaneka ragaman suku bangsa, agama, golongan-golongan dalam masyarakat.Keadaan ini mewarnai pola-pola kontak,interaksi,relasi dan komunikasi intraetnik maupun antara itnik sehingga orang indonesia lebih menyukai hubungan-hubungan "kekeluargaan,kekerabatan atau kekuasaan" "1

Teori Triple M,Menurut (1989), ada tiga unsur penting dalam teori ini, yaitu masyarakat massa,media massa, dan budaya massa. Ketiga unsur tersebut berkaitan satu sama lain membentuk satu segi tiga sebagaimana terlihat dalam gambar. Yang dimaksud dengan masyarakat massa adalah suatu sistem hubungan atau interaksi individu, individu dengan kelompok,kelompok dengan kelompok. Pada awalnya masyarakat masa merupakan masyarakat industri yang telah memilah-milah anggota masyarakat dalam sistem pembagian kerja berdasakan spesialisasi yang terkait satu sama lain. Dalam masyarakat massa, norma-norma dan moral selalu berubah terus menerus secara konstan. Hubungan antara individu ibarat"titik singgung" yang tidak diatur secara organik. Menurut Teori Triple M, memandang media massa merupakan media yang berfungsi sebagai pembagi pesan.Pesan-pesan yang dibagi dan dipertukarkan ke dalam masyarakat itu selalu mengandung nilai dan norma,ide-ide dan simbol yang mewakili pola pikir,perasaan,tindakan suatu masyarakat tertentu. Proses penukaran pesan melalui media massa didukung oleh perkembangan teknologi komunikasi yang memerlukan biaya yang semakin mahal sehingga timbullah paham ekonomi mediamassa dengan mengandalkan pengeluaran yang kecil namun pesan dapat menyebar luas kepada khalayak.

\section{PEMBAHASAN}

\section{ANALISIS SYSTEM PENDIDIKAN}

Menurut Wina Sanjaya (2006:2) menyatakan bahwa pendidikan menurut Undang-Undang No.20 tentang Sistem Pendidikan Nasional menyatakan nahwa pendidika adalah usaha sadar dan merancanakan untuk mewujudkan suasana belajar dan proses pembelajaran agar peserta didik secara aktif mengembangkan fotensi dirinya untuk memeliki kuatan spritual keagamaan, pengendalian diri, keperibadian,kecerdasan,akhlak mulia, serta keterampilan yang diperlukan dirinya, masyarakat, bangsa, dan negara.

Menurut Muwahid (2013: 7) menjelaskan bahwa Pendidikan didefinisikan sebagai proses seseorang mengembangkan kemampuan, sikap, dan tingkah laku lainnya di dalam masyarakat tempat mereka hidup. Pendidikan adalah proses pengubahan sikap, dan tingkah lakuseseorang atau kelompok orang dalam usaha mendewasakan manusia melalui upaya pengajaran, dan latihan-latihan. Dari apa yang telah disampaiakan oleh beberapa ahli tentang pendidkan bahwa pendidikan adalah usaha yang dilakaukan sacara sadar memberikan ilmu kepada anak didik tampa pamrih demi masa dapan bangsa dan negara (Ali Rommad, 2009:1).

${ }^{1}$.Aloliliweri,Komunikasi Antarbudaya ( Yogjakarta: Pustaka Pelajar,2011),205-207 
Menurut Mead (1943) pendidikan formal diatur keluarga kelihatannya baru akan mulai berkembang bila struktur social suatu masyarakat sudah cukup terdiferensiasi, sehingga anak-anak dapat memperoleh kedudukan dan peran yang berbeda dari orangtua mereka. Demikian pula bila keterampilan-keterampilan yang penting dan diingini telah demikian kompleks untuk pelajari dengan mudah, atau bila para orangtua sendiri tidak mungkin lagi mengajarkannya, maka keterampilanketerampilan tersebut akan diajarkan mula-mula oleh orang-orang yang dekat dengan anak-anak darimpekerjaan produktif menolong orangtua, dan perhatian dari kelompok-kelompok tertentu dalam mengawasi penguasaan pengetahuan dari keterampilan tertentu dan dalam memberi kesempatan kepada generasi muda menguasaunya untuk menjamin kesinambungan masyarakat dan kelestarian pengetahuan.

Dengan adanya factor-faktor pendorong seperti tersebut ditas maka berbagai masyarakat telah berkembang berbagai bentuk system persekolahan, termasuk dalam masyarakat sederhana dengan ekonomi yang masih bersifat subsistensi dan belum mempunyai aksara. Pemilihan aksara dapat dipakai salah satu factor kunci dalam menentukan tingkat perkembangan kebudayaan. Bahasa tertulis yang dimungkinkan oleh adanya aksara telah memunculkan suatu masyarakat untuk menumpuk pengalaman, mengkaji ulang pengalaman-pengalaman dari suatu generasi kegenerasi berikutnya yang akan menjurs kepada perkembangan ilmu pengetahuan yang menjadi motor pengerak perkembangan peradaban umat manusia.

Walaupun tipologi diatas bisa diperdebatkan kesahiannya, namun ia mengandung kebenaran untuk perkembangan persekolahan, ilmu pengetahuan, dan peradaban.Dalam bentuk lain Don Adams dan G. M. Reagan menggambarkan perkembangan pendidikan dan persekolahan serta hubungannya dengan perkemabangan diferensiasi masyarakat secara menarik sekali. Menurut mereka ada empat tahap perkembangan pendidikan dan hubungannya dengan perkembangan masyarakat.

Tahap pertama adalah pendidikan dalam masyarakat tanpa aksara. Pendidikan dalam masyarakat ini ditandai oleh proses belajar yang bersifat informal dalam keluarga dan hubungan-hubungan yang tersusun anatar satu generasi dengan generasi berikutnya untuk memberikan keterampilan-keterampilan ekonomi dan perkenalan prilaku social yang benar. Pada tahap ini peran-peran siswa dan pengajar ditentukan semata-mata tas dasar criteria yang bersifat askriptif. Anak-anak adalah "siswa" karna umur mereka; perbedaan apa yang dipelajari mereka ditentukan oleh jenis kelaminnya "pengajar" adalah pengajar karena mereka adalah anggota keluarga yang telah dewasa dan "spesialisasi" apapun yang dimilikinya juga ditentukan oleh jenis kelaminnya ; perempuan mengajar memasak dan laki-laki mengajarkan berburu.

Dalam tahap kedua, sebahagian dari proses sosialisasi mulai terdeferensiasi dari keluarga. Disini para remaja mulai dididik oleh sekelompok orang dewasa yang sudah terspesialisasi pengetahuan atau keterampilannya. Meskipun keterampilan dan pengetahuan praktis merupakan sebahagian dari "kurikulum" pendidikan, tapi tekanan kuat telah pula diberikan pada bidang-bidang mata fisika dan perilaku. "Bush School" di Afrika Barat merupakan contoh dari pendidikan pada tahap ini. ("Bush School" itu merupakan upacara inisiasi remaja masyarakat-masyarakat di Afrika Barat yang berlangsung cukup lama, bergerak dari enam bulan sampai delapan tahun. Selama masa ini mereka berada terpisah dari masyarakatnya, yaitu camp dalam hutan dan mereka diajar berbagai pengetahuan dan keterampilan budaya yang akan 
diperlukan mereka sebagai seorang dewasa. Sekolah itu lebih lama untuk remaja pria dibandingkan remaja putrid. Untuk pria dinamakan Poro, sedang untuk putrid dinamakan Sande ). Pada tahap kedua ini umur dan jenis kelamin merupakan penentu siapa yang jadi siswa. Perhatian terhadap pembawaan sudah mulai menetukan siapa yang bisa menjadi pengajar; latihan untuk lebih pandai dari orang biasa sudauh diberikan kepada guru. Dengan demikian spesialisasi sebagi pengajkar dengan tanggung jawab mengajar yang lebih besar sebagai pendidikan mulai berkembang. Disekolah ini semacam standar keberhasilan yang bersifat universal sudah mulai dikembangkan.

Pada tahap ketiga, ketika masyarakat sudah makin terdiferensiasi dan masalah seleksi social semakin besar, keluarga-keluarga atau kelompok-kelompok tertentu dalam masyarakat memperoleh kekuasaan yang lebih besar atau keuntungan ekonomi yang besar, dan pendidikan formal mulai tidak menjadi hak semua anggota masyarakat. Pendidikan mulai terlihat sebagai institusi yang dikaitkan kepada sekelompok-sekelompok yang relatif kecil yang memegang kekuasaan politik, ekonomi atau agam. Kondisi ini sesuai dengan konsep diferensiasi, karena kelompokkelompok yang ada di pusat proses diferenasiasi masyarakat dalam bidang ekonomi, politik, dan buadaya adalh, kelompok yang paling merasa perlu membangaun institusi pendidikan untuk menanamkan sikap-sikap dan nilai serta memberikan keterampilan-keterampilan yang diperlukan guna memelihara, menyesuaikan, dan memperkembang kelompok dan institusi-institusi mereka.

Criteria yang didasarkan pada askripsi, terutama dalam bentuk pertalian kelas, sangat kuat dalam menetukan siapa yang akan jadi siswa. Criteria untuk menentukan guru berhubungan erat dengan tingkat intelegensi atau bakat, guru diharapkan memiliki pengetahuan yang lebih tinggi. Kurikulum mencerminkan diferensiasi sesuai dengan tujuan yang ingin dicapai dan dipusatkan pada bahasa, pengetahuan umum, dan filsafah sebagai tambahan terhadap tata susila, hokum, dan agama. Partikularisme menjadi norma Karena individu-individu didik menurut kedudukan mereka.

Guru-guru terus mempunyai peran sebagai sumber ilmu tentang hidup, bukan sebagai spesialis dalam sebuah cabang ilmu pengetahuan terutama disekolah dasar dan menengah. Diferensiasi yang cukup menyangkut spesialisasi peran dapt terlihat dilembaga pendidikan tinggi dalam bentuk peran-peran administrasi dan spesialisasi dalam peran mengajar.

Pada tahap keempat, yaitu tahap yang paling maju terlihat hubungan antara pendidikan dan masyarakat menjadi rumit. Industrialisasi dan peningkatan diferensiasi masyarakatdiukur dengan pembagian kerja, dan spesiaslisasi peran menjadi cirri utama dari masyarakat.para pendidikan seringkali menyatakan bahwa tingkatan dan masalah pendidikan yang banyak yang disupervisi dan diajar oleh berbagai spesialis memegang peranan penting dalam memajukan industrialisasi dan dalam menanamkan nilai-nilai modern. Tahap ini memberikan beban yang besar kepada persekolahan dalam bentuk pendidikan masaal, persiapan bagi bermacam pekerjaan dan seleksi social.

Menyertai diferensiasi dan spesialisasi beberapa decade terakhir, terlihat ada dua perobahan pendidikan yaitu: 1)penyebaran dan ekspansi persekolahan, 2) asumsi peningkatan peran pendidikan formal dalam meningkatkan perobahan social ekonomi lebih lanjut. Pendidikan massal telah menjadi tujuan setiap bangsa. Meskipun di berbagai masyarakat bangsa persekolahan yang bersifat universal masih merupakan 
tujuan yang belum terpenuhi, namun dalam masyarakat yang paling kurang maju pun pendidikan dasar telah diberikan kepada sejumlah besar anak-anak yang dimasa lalu kebanyakan mereka tidak pernah bersekolah.

Peningkatan pemusatan system pendidikan dan perobahan social ekonomi yang direncanakan dan tidak direncanakan terlihat dalam beberapa hal. Sementara kemajuan telah dibuat kearah kehidupan modern, pencapaian atau keberhasilan pendidikan makin terus dikaitkan dengan prestise social dan status pekerjaan. Dalam masyarakat masa kini pendidikan masa kini pendidikan formal kelihatannya menjadi factor utama bagi mobilitas social dalam satu dan antar generasi.

Demikianlah, jalan kearah suskses bagi orang miskin dan cara memelihara status bagi yang telah memperolehnya berlangsung melalui system pendidikan. Lebih lanjut peningkatan tekanan pada "human resources" sebagai kunci pembangunan ekonomi telah meningkatkan pembenaran perluasan pendidikan. Dorongan yang kuat bagi adanya pembangunan ekonomi yang lebih besar dan persamaan yang lebih luas telah memberikan sumbangan terhadap peningkatan bobot atau arti penting dari pendidikan.

Walaupun hakekat yang tepat dari kontribusi pendidikan terhadap modernisasi dan pembengunan masih diperdebatkan namun yang jelas adalah barangkali sedikit sekali (kalau ada) pertentangan manyangkut generalisasi bahwa masyarakat modern dan maju memerlukan dukungan system pendidikan yang berkembang dengan baik. Tingkat pendidikan di negara-negara maju merupkan elemen penting dalam memelihara tingkat pembangunan yang tinggi. Hal tersebut terjadi disebabkan, pertama; dalam masyarakat maju produksi dan perdagangan semuanya menggunakan sitem keuangan. Ini berarti memerlukan system pembukuan yang luas, pengumpulan dan penyimpanan informasi yang cermat, dan pengaturan kontrak-kontrak yang kompleks. Hampir semua peran social memerlukan pengetahuan yang canggih dibandingkan dengan keperluan dalam masyarakat yang kurang maju. Bisa saja diperdebatkan apakah pengetahuan itu diperoleh melalui sekolah atau institusi lain. Yang kedua, dalam masyarakat modern kebanyakan komunikasi dilaksanakan secara tertulis. Hokum tertulis telah menggantikan hokum adat. Selanjutnya, keharusan social menyamgkut alokasi tenaga kerja didasarkan pada catatan mengenai lapangan kerja, lamaran tertulis, surat rekomendasi dan lain-lain. Peraturan pabrik, instruksi dan pedoman-pedoman, undang-undang mengenai upah dan jam kerja, semuanya itu menyebabkan diperlakukannya system pendidikan formal. Yang ketiga, ketergantungan masyarakat maju terhadap teknologi maju bersifat absolut. Didaerah perkotaan dimana lebih dari setengah penduduk berdomisili, kebutuhan akan makanan harus dipenuhi oleh system pertanian yang berteknologi maju atau diimpor dari luar negeri dengan membayar dengan hasil-hasil industri yang merupakan produk teknologi maju. Jumlah orang yang mempunyai kemampuan mengurus dan memanipulasi perlatan teknik terus bertambah besar dinegara maju. Arus yang besar dan tetap dari orang-orang yang kompeten secara teknis mesti dididik dan dilatih dalam setiap generasi, ini berarti pendidikan yang lebih tinggi bagi mayoritas penduduk.

\section{BUDAYA MASYARAKAT}

Budaya Masyarakat yang dimaksud dalam penelitian ini adalah menekankan kearah kebiasaan yang dianut masyarakat terhadap pendidikan anak perempuan dalam kehidupan sehari-hari. 
a. Pengertian Budaya (culture)

Secara etimologi, kata kebudayaan berasal dari bahasa sanskerta, buddhayahm bentuk jamak dari kata buddhi yang berarti akal atau budi. Menurut ahli budaya, kata budaya merupakan gabungan dari dua kata yaitu budi dan daya. Budi mengandung arti akal, pikiran, paham, pendapat,ikhtiar,perasaan, sedangkan daya mengandung makna tenaga,kekuatan,kesanggupan. Sekalipun kar budaya diderivisi dari akar kata yang berbeda, dapat dikatakan bahwa kebudayaan berkenaan dengan hal-hal yang berkenaan dengan budi atau akal.( Sulasman , 2013:7).

Menurut Kroeber dan Kluckhohn Budaya adalah (1).Definisi dekriptif cenderung melihat budaya sebagai totalitas koprehensif yang menyusun keseluruhan hidup sosial sekaligus menunjukkan sejumlah ranah (bidang kajian) yang membentuk budaya.(2).Definisi historis cenderung melihat budaya seabagai warisan yang dialihturunkan dari generasi berikutnya.(3). Definisi normatif bisa mengambil dua bentuk. Pertama budaya adalah aturan atau jalan hidup yang membentuk pola-pola perilaku dan tindakan yang kongkret. Kedua menekankan peran gugus nilai peran gugus nilai tanpa mengacu pada perilaku.(4).Definisi psikologis, cenderung memberikan tekanan pada peran budaya sebagai piranti pemecahan masalah yang membuat orang bisa berkomunikasi, belajar, atau memenuhi kebutuhan meterial maupun emosional.(5), Definisi Struktural, mau menunjukkan pada hubungan atau keterkaitan antara aspek-aspek yang terpisah dari budaya sekaligus menyoroti fakta bahwa budaya adalah absraksi yang berbeda dari perilaku konkret.(6), Definisi genetis, definisi ini yang melihat asal usul bagaimana budaya itu bisa eksis atau tetap bertahan. Definisi ini cenderung b materialistisudaya lahir dari interkasi antar manusia dan tetap bisa bertahan karena ditransmisikan dari satu generasi ke generasi berikutnya. (Mudji Sutrsno, 2005:910).

Dalam memahami kebudayaan materi ada dua pendekatan yang berbeda (1) Pendekatan idealistis dan (2) Pendekatan materialistis. Pendekatan idealistis berusaha mencari keunikan dari kebudayaan meteri dan berusaha mencari makna di balik terciptanya kebudayaan meteri melalui simbol-simbol yang tertuang di dalamnya. Dengan menggunakan interprestasi, sebuah kebudayaan meteri mampu diungkapkannya, misalnya mengungkapkan makna bahasa dengan apa yang disebut Bachtel sebagai model kognisi.Adapun pendekatan materialistis berusaha mencari buhungan antara kebudayaan materi dan perilaku manusia yang pernah membuat, mempergunakan, dan membuangnya. Pendekatan ini difokuskan pada objek materialnya,konfigurasi, artikulasi, sampai pada sifat-sifat molekulernya. Ada dua cara untuk memahami pola hubungan kebudayaan materi dengan perilaku manusianya, yaitu dengan etik dan emik.Mengenai cara ini,Marvin Harris membagi menjadi empat tipe (1).Tipe emics of thought,(2). Emics of behavior,(3).Etics of behavior,(4). Etics of thought. Marvin Harris juga mengungkapkan bahwa kebudayaan materi dapat mempengaruhi dan dipengaruhi oleh infrastruktur,struktur,dan superstruktur.( Sulasman, 2013, 49-50).

Buadaya berasal dari bahasa Sanskerta buddhayah yang merupakan bentuk jamak dari kata buddhi yang berarti akal atau budi. Menurut ahli budaya, kata budaya merupakan gabungan dari dua kata, yaitu budi dan daya (sidi Gazalba, 
1998 :35. Budi mengandung makna akal, pikiran, paham, pendapat,ikhtiar, perasaan, sedangkan daya mengandung makna tenaga, kekuatan kesanggupan. Sekalipun akar kata budaya diderivasi dari akar kata yang berbeda,dapat dikatakan bahwa kebudayaan merupakan hal-hal yang berkenaan budi atau akal.( Sulasman, 2013, 49-50).

b. Masyarakat,(society)

Masyarakat adalah suatu kelompok manusia yang telah memiliki tatanan kehidupan,norma-norma, adat istiadat yang sama-sama ditaati dalam lingkungannya. (M.Arifin Noor, 1999:85).Dalam bahasa Inggris masyarakat adalah 'society', yang berasala dari kata 'socuis', artinya kawan : sedangkan kata masyarakat berasal dari bahasa Arab yaiyu 'Syirk', artinya bergaul.Adanya saling bergaul ini tentu ada bentuk-bentuk aturan hidup,yang bukan disebabkan oleh manusia seseorang, melainkan oleh unsur-unsur kekuatan lain dalam limgkungan sosial yang merupakan kesatuan. Manusia mulai dari lahir sampai mati merupakan anggota masyarakat, mereka saling bergaul dan berintegrasi, karena mempunyai nilai-nilai, norma,cara-cara dan prosedur yang merupakan kebutuhan bersama. Dengan demikian dapatlah dikatan bahwa masyarakat merupakan kesatuan hidup manusia yang berintegrasi menurut suatu sistem adat-istiadat tertentu yang bersifat kontinu, dan terikat oleh suatu rasa identitas bersama. Selanjutnya dengan tercapainya sistem adat-istiadat atau sistem bergaul, kemudian diciptakan pula kaidah-kaidah atau norma-norma pergaulan yang akhirnya menciptakan suatu kebudayaan. Menurut Koentjaraningrat manyatakan bahwa masyarakat adalah kesatuan hidup dari mahluk-mahluk manusia yang terikat oleh suatu sistem adatistiadat yang tertentu, sedangkan Ralph linton menyatakan bahwa masyarakat adalah setiap kelompok manusia yang telah hidup dan bekerja sama cukup lama sehingga mereka dapat mengatur diri mereka dan menganggap diri mereka sebagai suatu kesatuan sosial denga batas yang dirumuskan dengan jelas,sedangkan menurut Selo Sumarjan masyarakat adalah orang-orang yang hidup bersama yang menghasilkan kebudayaan.( Wahru. 1986 :60-61). Oleh karena itu Budaya masyarakat adalah kehidupan sekelompok masyarakat yang hidup dalam suatu kelompok atau tempat yang terdiri dari berbagai suku bangsa dan adat istiadat yang menganut aturan-aturan tertentu, dalam mencapai ketertiban, kebahagiaan bersama dalam menjalani hidup didunia.

\section{PENDIDIKAN SEBAGAI MEDIA TRANSMISI BUDAYA}

Dalam konsersium ilmu pendidikan (1991) dijelaskan bahwa, pendidikan itu sebenarnya telah mulai dilaksanakan sejak manusia hadir dimuka bumi ini dalam bentuk pemberian warisan pengetahuan, keterampilan, dan nilai-nilai dari peran orang tua dalam rangka mempersiapkan anaknya menghadapi kehidupan. Pendidikan diarahkan untuk tujuan membentuk kedewasaan yaitu terbentuknya kemampuan menetapkan pilihan serta mempertanggung jawabkan perbuatan tingkah lakunya secara mandiri, dan setelah terbentuknya kedewasaan itu pendidikan dianggap selesai. Pada masa itu, pendidikan berlangsung secara sederhana kemudian dengan semakin kompleksnya tuntutan dan tantangan yang harus dihadapi, pendidikan menjadi lebih sistematis, terorganisir, yang diatur oleh lembaga yang terstruktur baik berupa sekolah maupun kursus-kursus. Tujuan 
pendidikan tidak hanya menyiapkan individu untuk menyesuaikan diri dengan lingkungan, tetapi diarahkan untuk pembentukan kemampuan mempertanyakan dan kesediaan melestarikan lingkungan. Implikasi dari pendidikan di atas adalah:

1. Pendidikan selalu melibatkan adanya interaksi sosial budaya antar peserta didik dengan pendidik.

2. Sebagai upaya yang dilakukan dengan sadar dan didalamnya selalu terkandung pesan (tujuan dan bahan) yang dijadikan acuan, proses atau cara yang ditempuh. Situasi lingkungan dimana proses itu berlangsung untuk mengetahui seberapa jauh pesan yang sampai dan terwujud dalam diri peserta didik.

3. Untuk memungkinkan tercapainya tujuan diharapkan pendidikan perlu diarahan pada pengemban seluruh dimensi kognitif, afektif dan psikomotor.

4. Pendidikan dapat ditinjau dari dua aspek: aspek mikro yang terdiri dari interaksi peserta didik dengan pendidik dan aspek makro yang terdiri dari kontek efektifitas dan efisiensi.

Dalam arti luas, pendidikan itu mencakup setiap proses, kecuali yang bersifat genetic, yang menolong membentuk pikiran, karakter atau kapasitas fisik seseorang. Proses itu berlangsung seumur hidup, karena kita harus mempelajari cara berfikir untuk bertindak yang baru dalam setiap perobahan besar dalam hidup kita. Dalam arti sempit pendidikan adalah penanaman pengetahuan, ketrampilan dan sikap pada masing-masing generasi dengan menggunakan pranata-pranata seperti sekolah-sekolah yang sengaja diciptakan untuk tujuan tersebut.

Dalam hubungannya dengan kebudayaan pendidikan merupakan media transmisi budaya atau institusi pewarisan nilai-niliai budaya. Pendidikan yang ditekankan disini adalah pendidikan formal dalam bentuk institusi sekolah. Disamping pendidikan formal, institusi yang juga berfungsi sebagai media transmisi budaya adalah institusi keluarga, tempat ibadah, kelompok sebaya dan mas media yang masing-masing dengan nilai dan tujuannya sendiri-sendiri (Imran Manan, 1988:10)

Dari deskripsi di atas dapat dipahami bahwa pendidikan adalah salah satu media transmisi budaya. Oleh karena itu pendidikan tersebut harus menilik kajiankajian antropologi dan ini mensyaratkan kerjasama antara pendidikan dan para antropolog dalam perencanaan pendidikan. Ringkasnya dalam misi pendidikan tersebut terdapat misi-misi kebudayaan yang berimplikasi kepada menjadikan kebudayaan sebagai bingka yang menjadi fundamen pendidikan.

Margaret Mead (dalam Haviland, 1988:406) menjelaskan, bahwa pendidikan masa kanak-kanak penting untuk pembentukan kepribadian orang dewasa. Kalau sebagian prilaku anak remaja merupakan hasil belajar dan bukan pembawaan biologis, maka memungkinkan dalam suatu kebudayaan untuk mengurangi sebanyak mungkin rasa gelisah dan tindakan-tindakan anti sosial yang dihubungkan dengan masa remaja dengan mengadakan perubahan kebudayaan. Kebalikannya, juga mungkin dengan mengubah cara pendidikan anak, kita akan mengubah struktur masyarakat. Fenomena kenakalan remaja, misalnya perkelahian atau penyalahgunaan obat terlarang yang terjadi akhir-akhir 
ini akan sangat menarik untuk dicermati melalui konsep kebudayaan yang dimaksud.

Pentingnya peranan pendidikan menyebabkan para ahli antropologi banyak menaruh perhatian dan mengakajinya, karena melalui pendidikan proses transmisi dan transformasi budaya dari genarasi kegenerasi berikutnya berlangsung, dan melalui pendidikan pula suatu bentuk kebudayaan itu dapat dipertahankan atau diubah.

\section{FORMAT PENDIDIKAN BERNUANSA BUDAYA}

Berbicara tentang pendidikan dalam hal ini pendidikan formal, adalah berbicara sekurang-kurangnya membicarakan unsur-unsur signifikan yang terlihat dalam proses pendidikan tersebut. Diantaranya bicara tentang kurikulum, guru, proses belajar mengajar. Disamping itu masih ada unsur-unsur pembantu dalam proses pendidikan tersebut, diantaranya: keluarga, masyarakat, mas media dan teman sebaya yang ikut dalam membentuk pola prilaku manusia. Format pendidikan yang bernuansa budaya berarti bagaimana membentuk atau merancang kurikulum, guru, siswa dan metodologi pengajaran dengan nilai-nilai dan norma-norma kebudayaan, sehingga menghasilkan produk pendidikan yang menjunjung tinggi nilai-nilai budaya atau produk pendidikan yang berkepribadian dengan kesadaran nilai yang dimilikinya, sehingga pola prilaku ditengah-tengah masyarakat menjadi tuntutan dan menjadi pedoman bukan menjadi tontonan karena kelucuan yang diperbuatnya di tengah-tengah masyarakat.

\section{KURIKULUM}

Secara etimologi. Kurikulum berasal dari bahasa Yunani yaitu "curir yang berarti pelari dan "curere" yang berarti jarak yang ditempuh oleh pelari. Istilah ini pada mulanya digunakan dalam dunia olah raga yang berarti suatu jarak yang harus ditempuh dalam pertandingan olah raga.

Dalam kontek pendidikan kurikulum adalah arena pertandingan, tempat belajar bertanding, untuk menguasai pelajaran guna mencapai garis penamat berupa ijazah atau gelar kesarjanaan. Jadi kurikulum adalah merupakan landasan yang digunakan pendidikan untuk membimbing peserta didik kearah tujuan pendidikan yang digunakan melalui akumulasi sejumlah pengetahaun ketrampilan dan sikap mental.

Nana Sudjana, (1991: 2), mengartikan kurikulum diartikan sejumlah mata pelajaran yng harus ditempuh oleh siswa untuk mencapai ijazah. Sedangkan S. Nasution, 1989:5) menjelaskan bahwa kurikulum sebagai pedoman belajar bagi siswa harus memiliki tujuan yang ingin dicapai. Isi program yang harus diberikan dan strategi atau cara bagaimanaa yang harus diberikan, dan strategi atau cara bagaimana melaksanakan program tersebut, tujuan program yan ingin dicapai dinyatakan dalam suatu rumusan mengenai tingkah laku yang diharapkan dan memiliki sisiwa setelah menerima $\mathrm{p}$ [rogram tersebut. Tujuan tersebut ada yang tujuan umum dan tujuan khusus.

Dalam menetapkan tujuan pendidikan dalam sebuah kurikulum, perancangan kurikulum tersebut harus memperhatikan "etika sain", yang berisi bahwa setiap ilmu yang dipelajari tersebut berfungsi untuk keselamatan manusia. 
Kesadaran akan nilai tersebut harus merupakan tujuan yang fundamental dalam sebuah kurikulum. Ini merupakan bentuk-bentuk nilai-nilai budaya yang bisa menjadi bingkai atau figura dari ilmu tersebut agar ilmu yang ditransferkan pada siswa dalam bentuk pembelajaran tersebut tidak menjadi "bumerang' kepada siswa, mahasiswa atau masyarakat untuk mensejahterakan manusia. Inilah bentukbentuk bingkai budaya yang harus ditekankan dalam sebuah kurikulum. Kemudian kurikulum tersebut juga dirancang sesuai dengan dinamika budaya agar ilmu itu tidak mubazir karena tidak "link" dengan kemajuan teknologi dan dunia kerja.

\section{GURU}

Guru merupakan faktor penting dalam proses pembelajaran, karena guru yang akan berhadapan langsung dengan peserta didik dalam proses belajar mengajar. Melalui guru pula ilmu pengetahuan dapat ditransferkan. Dalam lingkup lebih luas lagi guru merupakan faktor penting dalam mengimplimentasikan kurikulum, disamping kepala sekolah dan tenaga administrasi.

Senada dengan hal tersebut di atas Nana Sudjana (1991:9) menjelaskan bahwasannya guru harus: (1) menguasai kurikulum artinya menguasai tujuan kurikulum, isi program, sub pokok bahasan yang harus diberikan kepada sisiwa dan bagaimana memberikannya, (2) menguasai isi dari setiap pokok bahasan dengancara mempelajari buku-buku pelajaran yang berkenaan dengan pokok bahasan tersebut, (3) mampu menterjemahkan GBPP tersebut menjadi sustu program yang lebih optimal, sehingga guru setiap menstransferkannya kepada siswa melalui program pengajaran.

Keahlian tersebut di atas tentunya belum cukup, seorang guru harus menjadi figur teladan bagi siswa, guru harus menjadi simbol nilai dan norma yang dianut oleh masyarakat. Guru harus bisa menjadikan materi pelajarannya dicintai siswa. Seorang guru tidak hanya ilmunya yang menjadi panutan, tetapi juga segala prilakunya. Seorang guru juga harus mengerti latar belakang sosial budaya siswa yang mengatur pola perilakunya. Guru harus mengetahui latar belakang ekonomi keluarga peserta didiknya, seorang guru harus mengetahui tingkat kecerdasan siswa, mampu menjadi motivator dan dinamisator peserta didik dalam menempuh pendidikan serta guru harus mengerti dengan dinamika budaya. Pengetahuanpengetahuan inilah yang menjadi modal bagi guru dalam menentukan sikap prilakunya ditengah-tengah siswa didiknya.

\section{PROSES BELAJAR MENGAJAR}

Muhammad Narsan (1986) menyatakan bahwa belajar berkenaan dengan proses pelaksanaan interaksi ditinjau dari sudut peserta didik. Tepri-teori yang dikembangkan dalam komponan ini meliputi antara lain tentang karakteristik peserta didik, jenis dan cara belajar. Hirarki proses belajar dan kondisi belajar. Sedang mengajar berkenaan dengan proses pelaksanaan interaksi ditinjau dari sudut pendidik. Teori-teori yang berkembang disini adalah tentang karakteristik pendidikan model mengajar dan metode mengajar.

Adapun pun proses yang berbudaya terjadi bila adanya kesadaran diantara kedua belah pihak (guru dan sisiwa) sebagai konsumen ilmu dan produsen ilmu. Proses belajar dan mengajar yang berbudaya tidak menjadi siswa atau peserta 
didik sebagi objek ajar, tetapi menjadikan mereka sebagai mitra belajar, sehingga tidak menimbulkan superioritas dipihak guru dan sifat inferior dipihak sisiwa, akhirnya merusak proses belajar mengajar. Menjadikan peserta didik menjadi mitra belajar akan menciptakan suasana belajar yang demokratis. Oleh karena itu proses belajar mengajar yang demokratis merupakan salah satu bentuk dari proses belajr-mengajar yang berbudaya. Bentuk metode belajar yaknidengan metode yang berpotensi untuk membentuk jiwa inovatif, dinamis dan kreativitas pendidik.

\section{KELUARGA, MASYARAKAT, DAN PROSES TRANSMISI BUDAYA}

Confisius (dalam William J. Goode, 1991:2) Menyatakan bahwa kebahagiaan dan kemakmuran akan tetap ada dalam masyarakat jika saja semua orang bertindak "benar" sebagai anggota keluarga dan menyadari bahwa orang tersebut harus mentaati kewajibannya sebagai anggota masyarakat. Oleh karena itu bisa diapahami bahwa keluarga itu adalah elemen yang sangat menentukan dalam masyarakat. Penentu baik buruknya sebuah tatanan sosial. Jika damai dan harmonis sebuah keluarga akan berimplikasi kepada damai dan harmonisnya tatanan sosial akan tetapi jika berantakan dan cekcok sebuah keluarga akan bermuara kepada kekacauan masyarakat.

Keluarga merupakan fondasi bagi pendidikan anak pada masa selanjutnya. Makanya tidak mengherankan jika Golbert Highest (dalam Jamaluddin, 1988:20) menyatakan bahwa kebiasaan yang dimiliki anak-anak sebagian besar terbentuk oleh pendidikan keluarga. Sejak dari bangun tidur hingga kesaat akan tidur kembali. Anak-anak menerima pengaruh dan pendidikan dari lingkungan keluarga. Penanaman nilai-nilai tentang baik dan buruk yang harus dilakukan dan dilarang untuyk dilakukan merupakan bentuk dari proses pembudayaan ditengahtengah keluarga. Oleh karena itu orang tua yang peduli dengan pendidikan anakanak mereka akan berbuat seintensif mungkin dalam penanaman nilai-nilai dalam kurikulum semacam ini. Oarang tua yang selalu mentransimisikan nilai-nilai budaya ditengah-tenagah keluarganya akan tercipta keluarga yang sadar nilai akan menjadi teladan dalam masyarakat karena mereka selalu merefleksikan prilakuprilaku yang sesuai nilai dan norma-norma sosial yang berlaku. Anak-anak yang demikian akan sangat membantu proses transmisi budaya disekolah.

Disamping keluarga, masyarakat juga merupakan agen dari transmisi budaya pada individu atau anak. Masyarakat yang baik akan mensosialisasikan nilai-nilai yang baik dan benar kepada anak-anak atau anggota masyarakat ketimbang masyarakat yang tidak baik. Pendidikan masyarakat (civil education) mempunyai peran yang sangat signifikan dalam proses transmisi budaya. Dewasa ini dengan menguatnya budaya materialismme pragmatis telah membawa pada menguatnya semangat individualisme dikalangan masyarakat. Kalau pada dasawarsa tujuh puluhan ada anak- anak yang berkelahi dan diketahui masyarakat, masyarakat tersebut langsung menghentikannya dan memberikan nasehat bahwa berkelahi itu merupakan sifat yang tidak baik. Tetapi sekarang sikap atau jiwa pendidik masyarakt tersebut sudah berkurang atau menipis ditengah-tengah masyarakat, tidak saja dikota yang merupakan prototype masyarakat organnis tetapi juga didesa yang ciri solidaritas mekanismenya telah beransur ansur 
menghilang. Sekarang tawuran antar pelajar telah menjadi tontonan yang mengasikan bagi masyarakat ketimbang menghentikan dan menasehatinya. Pendidikan masyarakat dengan semangat kolektifnya dewasa ini telah dibenamkan oleh semangat individualisme materialis pragmatis. Namun kita tetap berharap dan berusaha masyarakat dapat menjadi agen sosialisasi nilai-nilai budaya ditengah-tengah masyarakat.

\section{HARAPAN TERHADAP MAS MEDIA}

Imran Manan (189:330 mengatakan mas media merupakan salah satu alat transmisi budaya, media cetak, elektronik (televisi, koran, majalah, internet) benar-benar memfungsikan dirinya menjadi alat transmisi budaya. Menjadi alat penanaman nilai-nilai dan norma-norma yang bisa membentuk kepribadian pemirsanya, bukan menjadi gangguan psikoligis atau alat pemotivasi lahirnya tindakan-tindakan yang bertentangan dengan nilai-nilai dan norma-norma yang berlaku ditengah-tengah masyarakat. Ringkasnya masa media tersebut bisa membentuk kepribadian yang positif bagi pemirsanya.

Fenomena mas media sekarang adalah kurang bernuansa budaya. Mas media sekarang informasi dan tampilan/tayangannya lebih banyak mengarah kepada pornografi, sadisme dan pelecehan. Agar hal tersebut tidak semakin meluas, maka beberapa waktu yang lalu Komisi Penyiaran Indonesia (KPI) menghimbau kepada televisi-televisi swasta untuk menghentikan tayangan yang mengarah kepada pornografi, sadisme dan pelecehan. Tampilan dan informasi semacam ini akan membentuk kepribadian yang tidak baik bagi pemirsanya, terutama anak-anak dan remaja yang masih dalam tataran meniru dalam pencarian identitas diri. Mereka masih dalam kondisi yang labil secara psikologis. Banyak sekali informasi yang kita dengar dan kita saksikan terjadinya pemekosaan dan pembunuhan gara-gara gangguan kejiwaan setelah menyaksikan dan membaca hal-hal yang berbau pornografi dan sadisme.Dalam kondisi labil yang dialami oleh anak-anak dan remaja, diharapkan sekali mas media yang bersifat edukatif untuk membentuk kepribadian mereka dengan menyuguhkan tayangan-tayangan yang positif untuk perkembangan jiwa seseorang.

\section{KESIMPULAN}

Dari uraian di atas dapat kita katakan bahwa, pendidikan bernuansa budaya bisa tercipta bila elemen-elemen pendidikan di atas bila elemen pendidikan formal seperti kurikulum, guru, proses belajar mengajar, siswa dan non formal seperti keluarga, masyarakat dan mas media sama dibingkai atau difigurai dengan nilai-nilai budaya, baik yang berasal dari nilai-nilai agama maupun nilai-nilai adat. Kita berharap adanya kebijakan mengenai pentingnya landasan budaya bagi pendidikan agar tercipta produk-produk pendidikan yang berkepribadian, yang mempunyai kesadaran nilai, menghargai nilai dan pencipta nilai.

Dalam pengertian yang besar, pendidikan sebagai transmisi pengetahuan yang disengaja, sistematis, tidak dapat dipahami sebagian-sebagian dari keseluruhan transmisi sosial budaya yang masuk.Focus pendidikan adalah terfokus pada kejadian-kejadian yang memerlukan sedikit usaha sadar (disengaja) untuk mentransfer pengetahuan dari seseorang atau kelompok untuk yang lainnya. 
Ini suatu hal yang kompleks dalam beberapa masyarakat meliputi sekelompok perwakilan (banyaknya agensi-agensi) banyaknya model-model komunikasi, dan banyaknya model kegiatan organisasi pendidikan.

Untuk menganalisis pendidikan itu sebagai system social budaya maka dibutuhkan peta distribusi sosial dari pengetahuan dan sekumpulan nilai-nilai sebagai uraian ringkas dalam bab ini. Hal itu juga dibutuhkan identifikasi penuh teratur dari kegiatan pendidikan dan konteks yang terjadi dalam masyarakat, untuk mengetahui hubungan timbal balik mereka.Banyak batasan-batasan dari aspek system pendidikan yang difokuskan pada sekolah-sekolah dan system sekolah. Untuk itu diperlukan data historical yang akurat (teat) dan dokumen agar kita dapat mrngembangkan sebuah system selama ini dinamis pelaksanaannya pada sebuah institusi yang besar dalam kerangkan social budaya.

\section{DAFTAR PUSTAKA}

Ali Rommad, 2009, Karita Selekta Pendidikan, Yogyakarta,Teras.

Agger, Ben.2003. Teori Sosial Kritis Kritik, Penerapan dan Implikasinya. Yogyakarta: Kreasi Wacana.

Anderson, Benedict., R. OG. 2001. Imagined Communities._Yogyakarta: Pustaka Pelajar Berry, David, 1982. Pokok-Pokok Dalam Sosiologi, Jakarta: Rajawali

Bagus, I Gusti Ngurah. 2002. Kearifan Lokal dalam Penganekaragaman Menuju Pembangunan Bali yang Berkelanjutan. Denpasar: UNUD

Buska, W., Prihartini, Y., \& Hasnah, N. 2018. Analysis of Students' Arabic Proficiency for Vocabulary Mastery in State Islamic Junior High School in Muaro Jambi. INNOVATIO: Journal for Religious Innovation Studies, 18(1), 51-62.

Buska, W., Prihartini, Y., \& Hasnah, N. 2018. Dirâsah Tahlîliyyah Taqwîmiyyah 'An Al-Mufradât Fî̀ Kitâb Manân Al-Azîz. Arabiyat: Jurnal Pendidikan Bahasa Arab dan Kebahasaaraban, 5(2), 358-373.

Danandjaja, James.1994. Antropologi-Psikologi, Teori, Metode dan Sejarah Perkembangannya. Jakarta: Raja Grafindo Persada.

Djati Sidi, Indra. 2001. Menuju Masyarakat Belajar Menggagas Paradigma Baru Pendidikan. Jakarta: Paramadina.

David Kaplan,2012, Teori Budaya,Yogjakarta: Pustaka Pelajar.

Goode, S. William, 1991. Sosiologi Keluarga. Jakarta: Bumi Aksara

Geertz, Hildred. 1981. Aneka Budaya dan Komunitas di Indonesia. Jakarta:Obor.

Jalaluddin, 1998. Psikologi Agama. Jakrta: Rajawali

Koentjaraningrat, 1991. Pengantar Ilmu Antropologi. Jakarta: Rineka Cipta

Konsersium Ilmu Pendidikan, 1990. Hasil study penataan fakultas. Jakarta: Dikti

Kusumohamidjojo, Budiono. 2001. Kebhinekaan Masyarakat di Indonesia Suatu Problematik Filsafat Kebudayaan. Jakarta: Gramedia.

Muwahid, 2013, Manajemen Pendidikan Islam, Yogyakarta,Teras.

Manan, Imran, 1989. Dasar-Dasar Sosial Budaya Pendidikan, Jakarta: P\&K

Mudji Sutrsno,2005, Teori-Teori Kebudayaan, Yogyakarta,Penerbit Kanisius.

M.Arifin Noor,1999, Ilmu Sosial Dasar, Bandung,Pustaka Setia.

Noerhadi, Tuty Herati.1987. Evaluasi Strategi Kebudayaan dalam Pengembangan Kesenian. Evaluasi dan Strategi Kebudayaan . Jakarta: UI Depok

Nur Uhbiyati, 1998, Ilmu Pendidikan Islam, Bandung :Pustaka Setia. 
Prihartini, Y. 2018. Peningkatan Maharah Al Kitabah Melalui Penerapan Media Lauhah Al Juyub Pada Siswa Mtsn Aceh Utara. Jurnal Literasiologi, 1 (1), 2020.

Prihartini, Y., \& Wahyudi, W. 2018. The Development of Integrated Learning Model To Improve Language Skills at Arabic Language. IJER (Indonesian Journal of Educational Research), 3(1), 9-14.

Prihartini, Y., Wahyudi, W., Aliasar, A., Mukhaiyar, M., \& Ungsi, A. O. M. 2018. The Development of Arabic Learning Model by Using Multimedia of Computer at UIN STS Jambi. Al-Ta lim Journal, 25(2), 135-143.

Prihartini, Y., Wahyudi, W., Nuraini, N., \& DS, M. R. 2018. Penerapan Konsep Matematika Dalam Pembelajaran Bahasa Arab Pada FTK Di UIN STS Jambi. Tarbawi: Jurnal Ilmu Pendidikan, 14(2), 15-28.

Raharjo, Dawam, 1985. Pergulatan Bumi Pesantren. Jakarta: P3M

Sardar, Zianuddin dan Borin Van Loon. 2001. Mengenal Cultural Studies for Beginners. Bandung: Mizan.

Sindhunata (Ed). 2000. Menggagas Paradigma Baru Pendidikan, Demokrasi, Otonomi, Civil Society, Globalisasi. Yogyakarta: Kanisius.

Sulasman,2013, Teori-teori Kebudayaan, Bandung, Pustaka Setia,

Tilaar, H.A.R. 2000. Paradigma Baru Pendidikan Nasional. Bandung: Rineka Cipta.

Teneko B. Soeleman, 1990. Struktur dan Proses Sosial. Jakarta: Rajawali

Tilaar, HAR. 1999. Pendidikan, Kebudayaan dan Masyarakat Madani Indonesia Strategi Reformasi Pendidikan Nasional. Bandung: Rosdakarya.

Tilaar, HAR. 1998. Manajemen Pendidikan Nasional. Bandung: Rosdakarya

Wahru,1986, Wawasan Ilmu Sosial Dasar, Surabaya Usaha Nasional.

Wahyudi, W. 2018. 2 Play And Work In The Curriculum Suatu Tinjauan Filsafat tentang Pengembangan Kurikulum PAUD. SMART KIDS: Jurnal Pendidikan Islam Anak Usia Dini, 1(1), 9-21.

Wahyudi, W. (2018). Tingkat Kelayakan Tes Uas Bahasa Arab Pada Fakultas Ilmu Tarbiyah Dan Keguruan Di Uin Sulthan Thaha Saifuddin Jambi Tahun Ajaran 2016-2017. Jurnal Al-Ashlah, 1(2).

Wahyudi, W., \& Prihartini, Y. (2019, April). Development of Arabic Learning Material Based on Eclectic Method. In 3rd Asian Education Symposium (AES 2018). Atlantis Press.

Warman, Suwarsih. 2002. Stereotip Etnis dalam Masyarakat Multi Etnis. Yogyakarta: Matabangsa.

Wertheim, WF. 1999. Masyarakat Indonesia dalam Transisi Studi Perubahan Sosial. Yogyakarta: Tiara Wacana.

Wina, Sanjaya, 2006, Strategi Pembalajaran Berorentasi Standar Proses Pendidikan, Jakarta, Kencana Prenada Media.

Yusraini, Y., \& Prihartini, Y. 2017. Pembelajaran Bahasa Arab Di Iain Sulthan Thaha Saifuddin Jambi. Penamas, 27(2), 219-230.

Zamroni.2000. Paradigma Pendidikan Masa Depan. Yogyakarta: Bigraf Publishing. 